\title{
Erratum to: Catalytic Properties of Two Rhizopus oryzae 99-880 Glucoamylase Enzymes Without Starch Binding Domains Expressed in Pichia pastoris
}

\author{
Jeffrey A. Mertens • Jay D. Braker - Douglas B. Jordan
}

Published online: 13 July 2010

(C) Springer Science+Business Media, LLC 2010

\section{Erratum to: Appl Biochem Biotechnol \\ DOI 10.1007/s12010-010-8994-0}

In the original publication, Fig. $3 \mathrm{a}$ and $\mathrm{b}$ are the same image. The corrected figure is reproduced here.

a

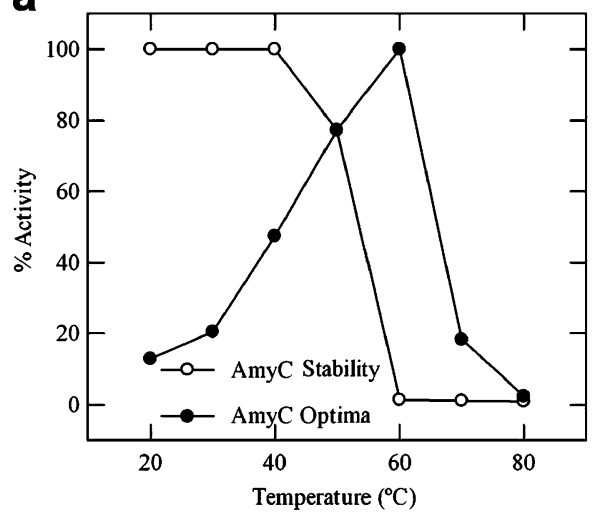

b

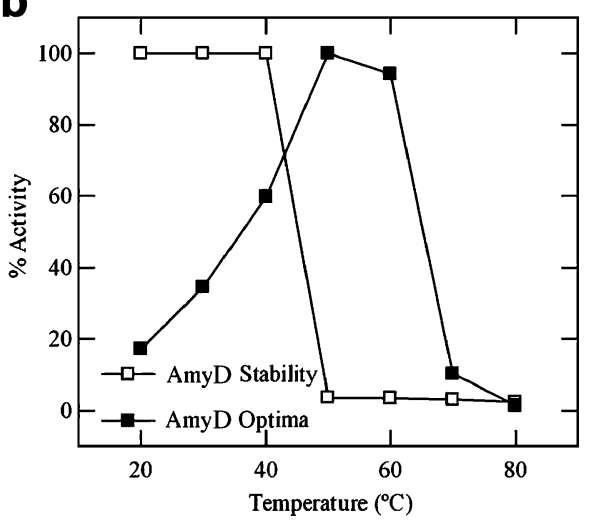

Fig. 3 Temperature stabilities and optima of AmyC and AmyD. Temperature stabilities of AmyC at $\mathrm{pH} 5.5$ and AmyD at $\mathrm{pH} 6.0$ were determined by pre-incubating the enzymes for $30 \mathrm{~min}$ at $20^{\circ} \mathrm{C}$ to $80^{\circ} \mathrm{C}$ followed by activity assays $\left(1 \%\right.$ soluble starch) at $40{ }^{\circ} \mathrm{C}$. Temperature optima of AmyC and AmyD were determined by performing activity assays ( $1 \%$ soluble starch) at temperatures ranging from $20{ }^{\circ} \mathrm{C}$ to $80{ }^{\circ} \mathrm{C}$. For temperature optima, $100 \%$ activity corresponds to rate of $94.9 \mathrm{~s}^{-1}$ and $49.7 \mathrm{~s}^{-1}$ for AmyC and AmyD, respectively

The online version of the original article can be found at http://dx.doi.org/10.1007/s12010-010-8994-0.

J. A. Mertens $(\bowtie) \cdot$ J. D. Braker $\cdot$ D. B. Jordan

Bioenergy Research Unit, National Center for Agricultural Utilization Research,

USDA Agricultural Research Service, 1815 N. University St., Peoria, IL 61604, USA

e-mail: jeffrey.mertens@ars.usda.gov 